\title{
The three-factor model of Internet addiction: The development of the Problematic Internet Use Questionnaire
}

\author{
Zsolt Demetrovics, Beatrix Szeredi, ANd SÁndor Rózsa \\ Eötvös Loránd University, Budapest, Hungary
}

\begin{abstract}
Despite the fact that more and more clinical case studies and research reports have been published on the increasing problem of Internet addiction, no generally accepted standardized tool is available to measure problematic Internet use or Internet addiction. The aim of our study was to create such a questionnaire. On the basis of earlier studies and our previous experience with Young's (1998a) Internet Addiction Test, initially, we created a 30-item questionnaire, which was assessed together with other questions regarding participants' Internet use. Data were collected online from 1,037 persons ( $54.1 \%$ of them male; mean age, 23.3 years; $S D, 9.1)$. As a result of reliability analysis and factor analysis, we reduced the number of items to 18 and created the Problematic Internet Use Questionnaire (PIUQ) containing three subscales: obsession, neglect, and control disorder. Cronbach's $\alpha$ of the PIUQ is .87 (Cronbach's $\alpha$ of the subscales is .85, .74, and .76, respectively). The test-retest correlation of the PIUQ is .90. The PIUQ proved to be a reliable measurement for assessing the extent of problems caused by the "misuse" of the Internet; however, further analysis is needed.
\end{abstract}

After the appearance of the Internet, the sudden explosion of its use soon drew attention to this phenomenon (Belsare, Gaffney, \& Black, 1997; Griffiths, 1997; Young, 1996, 1998a). The earliest investigations revealed that Internet use, besides its enormous advantages, also carries the possibility of abuse and the potential danger that addiction could develop (Brenner, 1997). According to research results, intensive Internet use is related to neglect of other life areas - thus, with declining educational and work achievement, decreasing sleeping time, reduced quality of meals, and a narrowing range of interests (see, e.g., Chou, Condron, \& Belland, 2005; Nalwa \& Anand, 2003; Young, 1998b). An excessive amount of Internet use also has a negative effect on family and partner relations and on communication within the family (Kraut et al., 1998). Also, there is an increasing amount of data that support the hypothesis that different mental and conduct problems are frequently associated with intensive Internet use. In this regard, Internet addicts have been proven to score higher on loneliness scales (Morahan-Martin \& Schumacher, 2000; Nalwa \& Anand, 2003; Whang, Lee, \& Chang, 2003), and they seem to be more introverted (Koch \& Pratarelli, 2004) and shy in face-to-face interactions (Chak \& Leung, 2004; Yuen \& Lavin, 2004). They also have reported lower self-esteem (Armstrong, Phillips, \& Saling, 2000) and a higher level of depression (Whang et al., 2003; Young \& Rodgers, 1998). Psychiatric disorders, especially anxiety and mood disorders, are more prevalent among those dependent on the Internet, and sub- stance use disorders also seem to be frequent comorbid states among Internet addicts (Bai, Lin, \& Chen, 2001; Shapira, Goldsmith, Keck, Khosla, \& McElroy, 2000).

Despite increasing interest and attention of researchers, even today there are several questions in the area to which the answers are unclear, some of which cause difficulties in the interpretation and comparison of the above-mentioned research findings. These unclarified matters include three closely related problem areas: terminology, diagnostic conceptions, and measurement. In the field of terminology, there is a relatively significant heterogeneity. Besides Internet addiction (Goldberg, 1995), there is widespread use of the following terms: problematic Internet use (Caplan, 2002; Shapira et al., 2003), pathological Internet use (Morahan-Martin \& Schumacher, 2000), compulsive Internet use (Greenfield, 1999), and excessive Internet use (Hansen, 2002). Use of terminology is, of course, closely related to the conception that lies behind it. Such terms as Internet addiction or pathological Internet use implicitly claim that this phenomenon should be included as an independent, genuine psychiatric disorder among other mental disorders listed in the $D S M-I V$ (American Psychiatric Association, 1994). In early descriptions, this approach was predominant, although views differed on which disorder would be the best starting point for the clinical description of Internet addiction: substance use disorder or impulse control disorders - primarily, pathological gambling. Later, partly because of the dispute as to whether Internet addiction was a separate disorder (Griffiths, 2000; 
Mitchell, 2000; Morahan-Martin, 2005; Treuer, Fábián, \& Füredi, 2001), using the term excessive or problematic Internet use became more frequent. Besides the recognition of the addictive nature of this phenomenon, there has been an increasing effort to identify compulsive and impulse symptoms and work/educational problems resulting from excessive Internet use.

The development of assessment tools has basically happened in the same way. As a first approach, Goldberg (1995) tried to describe the phenomenon of Internet addiction by using the criteria for psychoactive substance dependence. He recommended that the DSM- $I V$ diagnostic criterion for chemical addictions (American Psychiatric Association, 1994) be extended to the phenomenon of Internet addiction. Brenner (1997) also took the criteria for substance dependence as a starting point and created a 32-item-long questionnaire (working title: InternetRelated Addictive Behavior Inventory), which, like the above-mentioned instrument, has never been used. Young (1996) initially believed that Internet addiction was similar to other (behavioral) addictions, and she thought that chemical substance addiction could be a proper model for the phenomenon. Later, she defined excessive Internet use as a phenomenon similar to pathological gambling (Young, 1998b). In her eight-question Diagnostic Questionnaire, dependents are classified by a minimum of five yes answers. Although this Diagnostic Questionnaire has sometimes been used in research, it has never been subjected to systematic psychometric testing. The other scale created by Young (1998a), the 20-item Internet Addiction Test, shows sufficient inner consistency (Widyanto \& McMurran, 2004).

Recently, several theory-driven instruments have been created. Davis's (2001) cognitive-behavioral model of Pathological Internet Use distinguishes between specific and generalized pathological Internet use. The former refers to a pathological use of one area of the Internet, and the latter refers to a generally problematic Internet use. Caplan (2002) conducted a study based on the model of Davis, and he identified seven components of problematic Internet use: mood alteration, perceived social benefits available online, negative outcomes associated with Internet use, compulsive Internet use, excessive amounts of time spent online, withdrawal symptoms when away from the Internet, and perceived social control available online. Caplan's Generalized Problematic Internet Use Scale proved to be reliable and valid according to the author's preliminary results; however, we do not know of further research with this tool. Davis, Flett, and Besser (2002) used the Online Cognition Scale to reveal four dimensions of problematic Internet use: diminished impulse control, loneliness/depression, social comfort, and distraction. Nichols and Nicki (2004) added two additional items (salience and mood modification) to the seven $D S M-I V$ criteria for substance use dependence, and they created a 36-item questionnaire: the Internet Addiction Scale. On the basis of psychometric analysis, they decreased the number of items to 31 . Contrary to abovementioned works, they identified only one general factor. The work of Pratarelli and his coworkers is also notewor- thy. With the use of a 74-item questionnaire, they identified four factors describing Internet use: Internet addiction, Internet use, a sexual factor, and unproblematic issues of computer-Internet use (Pratarelli \& Browne, 2002; Pratarelli, Browne, \& Johnson, 1999). Besides the abovementioned ones, Beard (2005) refers to some unpublished instruments and other - not scalelike - ad hoc sets of questions used in several studies (see, e.g., Morahan-Martin \& Schumacher, 2000; Yuen \& Lavin, 2004).

It can be concluded that although the aim of several studies has been to set up a model of problematic Internet use, a widely accepted frame including an assessment instrument has not yet been created. Instead, there have been several experiments, partly complementing each other and partly competing. However, for further research on the phenomenon of Internet addiction, it is necessary to have a valid and reliable tool to be able to estimate the seriousness of problems related to the Internet use habits of research participants. Without such an instrument, investigation of the phenomenon will be like describing the characteristics of Internet addiction without an exact definition of what is meant by this phenomenon. The aim of the present study is to contribute to this goal. On the one hand, our aim is to present a questionnaire that is appropriate to measure problems and harms associated with Internet use and that may later be used to create a diagnostic tool. On the other hand, it is also our aim to identify the components of problematic Internet use.

\section{METHOD}

\section{Participants}

A total of 1,064 participants completed the questionnaires, of which 27 questionnaires had to be dropped due to inconsistencies or lack of relevant answers. According to the analyzed 1,037 questionnaires, $54.1 \%$ of the participants were males. The mean age was 23.3 years $(S D=9.1)$. More than half of the respondents were primarily students $(51.3 \%)$, whereas $43.8 \%$ worked. The rate of those not having a permanent occupation was $3.3 \%$. Almost a quarter of the participants $(24 \%)$ had a higher education degree, whereas the proportion of high school graduates was $43.7 \%$ (see Table 1).

Table 1

Important Demographic Data for the Research Participants $(N=1,037)$

\begin{tabular}{lccc}
\hline \multicolumn{1}{c}{ Characteristic } & $\%$ & $M$ & $S D$ \\
\hline Sex & & & \\
$\quad$ Male & 54.1 & & \\
$\quad$ Female & 45.9 & & \\
Age (years) & & 23.6 & 8.6 \\
$\quad$ Male & & 23.0 & 9.6 \\
$\quad$ Female & & 23.3 & 9.1 \\
$\quad$ Total & & & \\
Primary Occupation & 51.3 & & \\
$\quad$ Study & 43.8 & & \\
$\quad$ Work & 3.3 & & \\
$\quad$ No occupation & 1.6 & & \\
$\quad$ Other & & & \\
Highest Degree of Education & 32.3 & & \\
$\quad$ No high school graduation & 43.7 & \\
$\quad$ High school graduation & 43.0 & \\
$\quad$ Higher education degree & 24.0 & \\
\end{tabular}




\section{Measures}

Demographic data. Eight questions were constructed about the participants' sex, age, partner relations, residency, qualifications, and so forth.

Characteristics of computer and Internet use. Computer and Internet use habits of the participants were examined in 25 questions.

Problems related to Internet use. In a previous study (Nyikos, Szeredi, \& Demetrovics, 2001), a questionnaire of 30 items was constructed to measure problematic Internet use (the Internet Addiction Questionnaire). The questionnaire partly consisted of the items on Young's (1998a) Internet Addiction Test (IAT) or their modifications (first 20 items). Additional items were constructed by considering symptoms described in the literature of problematic Internet use (Items 21-30). This supplement was needed for several reasons. On the one hand, the first psychometric analysis of the IAT (Widyanto \& McMurran, 2004) revealed that the original items of the IAT did not cover all hypothetical aspects. On the other hand, descriptions of problematic Internet use that had appeared since the creation of the IAT also justified modification and supplementation of the questionnaire. For every question of the IAT, participants had to estimate how much the given statement was true for them on a scale between 1 (never) and 5 (always).

Other measures. Since this study was a part of a broader research project, several other psychological characteristics (depression, interpersonal relationship, anxiety, satisfaction with life, etc.) were investigated. However, in this article, only a psychometric analysis of the questionnaire measuring problems related to Internet use will be presented, and results in connection with other dimensions will not be considered.

\section{Procedure}

The participants were informed that the purpose of this study was to examine the components and characteristics of Internet use. Data were collected online. According to the results of Cronk and West (2002), as compared with the paper-and-pencil method, online data collection may affect response rates, but not the results.

\section{RESULTS}

\section{Creation of the Problematic Internet Use Questionnaire (PIUQ)}

Analysis of reliability. An analysis of reliability on the original 30 items resulted in a Cronbach's $\alpha$ of .91 . The corrected item-total correlation was between .26 and .66. A weak correlation (under .3) was found only for two items (Items 7 and 23; see Table 2).

Factor analysis. A principal component analysis with varimax rotation was made for the 30 items. The analysis resulted in a four- and a three-factor solution. In the former solution, the first three factors corresponded to the factors of the three-factor solution, but there was an additional fourth factor consisting of only 3 items. Since all these items had a high weight in one of the first three factors, we decided to use the three-factor solution. These three factors explained $41.96 \%$ of the variance (Table 2 ).

The first factor included 11 items. The substance of these items was, on the one hand, mental engagement with the Internet - that is, daydreaming, fantasizing a lot about the Internet, waiting for the next time to get online - and, on the other hand, anxiety, worry, and depression caused by lack of Internet use. This factor was called the obsession scale.

The second factor included 10 items. The substance of these items was neglect of everyday activities and essential needs. Items about the decreasing importance of household chores, work, studies, eating, partner relations, and other activities and the neglect of these activities due to an increased amount of Internet use were included. Thus, this factor was named the neglect scale.

The third factor included eight items. These items referred to difficulties in controlling Internet use. They expressed the fact that the person used the Internet more often and/or for a longer time than had previously been planned and that, despite his or her plans, he or she was not able to decrease the amount of Internet use. Items also referred to perceiving Internet use as a problem. This factor was named the control disorder scale.

Reduction of number of items. Subsequently, each item was reviewed on the basis of its weight within the scale, its corrected item-total correlation value, and its meaning in order to reduce scales and create a clear-cut factor structure. The frequency of not getting answers to the items from the participants was also considered. As a result of this reduction, three subscales were created, each containing six items (see Table 3).

Internal consistency of the PIUQ. On the basis of the reliability analysis of the three scales (Table 4), it can be concluded that Cronbach's $\alpha$ was between .74 and .87 for all three subscales and for the main scale as well, which indicates a high consistency of scales. In accordance with this, after the investigation of the subscales, a high itemtotal correlation of more than 4 was found for all the items except one (Item 18). After the analysis of the total scale, all the values except one (Item 18) were greater than .38 .

Correlation of scales. The correlation of subscales with each other was around .5, and the correlations of the total scale with each subscale was greater than .8 (Table 5).

Pre-post reliability of the PIUQ. Test-retest reliability of the scales was checked by Pearson correlation. Sixty-three university students participated in the study, who filled out the questionnaire again after 3 weeks. The data were collected in groups after a university lecture. The correlations of the scales are presented in Table 6 . For the main scale, the correlation of pre-post data collections was high $(.903 ; p<.0001)$. The correlations of the subscales were found to be between .763 and $.904(p<$ .0001 in all cases; see Table 6).

\section{Problematic Internet Use and Sociodemographic Characteristics}

For the PIUQ main scale, no significant gender differences were found. However, in the case of the control disorder dimension, women had a significantly higher mean score than did men, and in the case of the neglect dimension, men had a significantly higher mean score than did women (see Table 7).

Age had a significant influence on the results for both the main scale and the subscales. Thus, the youngest people, those under 18, scored the highest values on all the scales (see Table 8).

There was no significant difference between people with university degrees and people with high school diplomas; however, the results for people not graduating from high school on all the subscales and on the PIUQ 
Table 2

Results of Factor Analysis With Varimax Rotation on 30 Items

\begin{tabular}{|c|c|c|c|c|c|}
\hline Item & $\begin{array}{l}\text { Factor I: } \\
\text { Obsession }\end{array}$ & $\begin{array}{l}\text { Factor II: } \\
\text { Neglect }\end{array}$ & $\begin{array}{l}\text { Factor III: } \\
\text { Control } \\
\text { Disorder }\end{array}$ & Comm. & $\begin{array}{l}\text { Corrected } \\
\text { Item-Total } \\
\text { Correlation }\end{array}$ \\
\hline 27. How often do you daydream about the Internet? & .789 & & .139 & .644 & .533 \\
\hline $\begin{array}{l}\text { 15. How often do you fantasize about the Internet, or think about what it would } \\
\text { be like to be online when you are not on the Internet? }\end{array}$ & .752 & .198 & .143 & .626 & .607 \\
\hline $\begin{array}{l}\text { 25. How often do you feel tense, irritated, or stressed if you cannot use the In- } \\
\text { ternet for as long as you want to? }\end{array}$ & 693 & .242 & .222 & .589 & .637 \\
\hline $\begin{array}{l}\text { 28. How often do you feel tense, irritated, or stressed if you cannot use the In- } \\
\text { ternet for several days? }\end{array}$ & .669 & .321 & .135 & .569 & .630 \\
\hline $\begin{array}{l}\text { 20. How often does it happen to you that you feel depressed, moody, or ner- } \\
\text { vous when you are not on the Internet and these feelings stop once you are } \\
\text { back online? }\end{array}$ & 633 & .256 & .217 & .513 & .603 \\
\hline $\begin{array}{l}\text { 12. How often do you think that your life would be empty, boring and joyless } \\
\text { without the Internet? }\end{array}$ & 631 & .407 & & .568 & .624 \\
\hline 26. How often do you dream about the Internet? & .630 & & .132 & .417 & .383 \\
\hline $\begin{array}{l}\text { 11. How often do you realize that you are waiting for the minute when you can } \\
\text { use the Internet again? }\end{array}$ & .618 & .424 & .129 & .579 & .662 \\
\hline $\begin{array}{l}\text { 10. How often do you push disturbing thoughts about your life away by the } \\
\text { calming world of the Internet? }\end{array}$ & .480 & .375 & .199 & .411 & .578 \\
\hline $\begin{array}{l}\text { 13. How often do you snap, yell, or act annoyed if someone bothers you while } \\
\text { you are online? }\end{array}$ & .436 & .369 & .145 & .347 & .518 \\
\hline $\begin{array}{l}\text { 30. How often do you feel that you cannot concentrate on your work because } \\
\text { you are thinking about the Internet? }\end{array}$ & .423 & .174 & .357 & .337 & .493 \\
\hline 2. How often do you neglect household chores to spend more time online? & .177 & .733 & .176 & .599 & .600 \\
\hline 14. How often do you spend time online when you'd rather sleep? & .144 & .624 & & .417 & .470 \\
\hline 3. How often do you choose the Internet rather than being with your partner? & .102 & .572 & & .340 & .396 \\
\hline 8. How often does the use of the Internet impair your work or your efficacy? & & .531 & .327 & .392 & .468 \\
\hline $\begin{array}{l}\text { 5. How often do people in your life complain about spending too much time } \\
\text { online? }\end{array}$ & .266 & .528 & .236 & .405 & .556 \\
\hline $\begin{array}{l}\text { 6. How often do you get bad marks or neglect your studies because of the } \\
\text { Internet? }\end{array}$ & .113 & .474 & .209 & .281 & .415 \\
\hline $\begin{array}{l}\text { 19. How often do you choose the Internet rather than going out with somebody } \\
\text { to have some fun? }\end{array}$ & .298 & .457 & & .307 & .463 \\
\hline 21. How often do you forget to eat because of being online? & .311 & .423 & .122 & .290 & .465 \\
\hline $\begin{array}{l}\text { 29. How often does it happen to you that you spend time on obtaining items } \\
\text { (books, software) that you need for Internet usage? }\end{array}$ & .224 & .410 & & .225 & .310 \\
\hline 4. How often do you establish new relationships with other online users? & .276 & .308 & .114 & .184 & .375 \\
\hline 7. How often do you check your new e-mails before doing any necessary task? & & .286 & .173 & .114 & .258 \\
\hline $\begin{array}{l}\text { 24. How often do you feel that you should decrease the amount of time spent } \\
\text { online? }\end{array}$ & & .222 & .760 & .627 & .457 \\
\hline $\begin{array}{l}\text { 17. How often does it happen to you that you wish to decrease the amount of } \\
\text { time spent online but you do not succeed? }\end{array}$ & .130 & .285 & .720 & .616 & .563 \\
\hline 18. How often do you try to conceal the amount of time spent online? & .224 & & 645 & .467 & .421 \\
\hline 22. How often do you feel that your Internet usage causes problems for you? & .170 & .162 & .602 & .417 & .448 \\
\hline 1. How often do you find that you stay online longer than you intended? & & .425 & .500 & .433 & .437 \\
\hline $\begin{array}{l}\text { 16. How often do you realize saying when you are online, "just a couple of } \\
\text { more minutes and I will stop"? }\end{array}$ & .253 & .289 & .488 & .385 & .528 \\
\hline $\begin{array}{l}\text { 23. How often do you think that you should ask for help in relation to your } \\
\text { Internet use? }\end{array}$ & .233 & & .461 & .273 & .286 \\
\hline $\begin{array}{l}\text { 9. How often do you start to defend yourself, or conceal reality when some- } \\
\text { one asks about what you do on the Internet? }\end{array}$ & .259 & .126 & .366 & .217 & .375 \\
\hline Explanatory strength of factors (\%) & 16.802 & 13.788 & 11.373 & & \\
\hline
\end{tabular}

Note-Comm., communality. Values under .1 are not included. Boldface indicates that the item belongs to this particular factor.

main scale indicated a higher degree of Internet dependency than for people in the other two groups. There was a lower level of problematic Internet use found among working people than among students and people not having any occupation.

\section{Characteristics of Internet Use and Problematic Internet Use}

Of the participants, $92.4 \%$ had a computer at home, and 4 out of 5 people $(80.9 \%)$ also had access to the Internet at home. Of the latter group, $82.7 \%$ preferred using 
Table 3

Factor Structure of 18-Item-Long PIUQ

\begin{tabular}{|c|c|c|c|}
\hline Item & $\begin{array}{l}\text { Factor I: } \\
\text { Obsession }\end{array}$ & $\begin{array}{c}\text { Factor II: } \\
\text { Neglect }\end{array}$ & $\begin{array}{c}\text { Factor III: } \\
\text { Control } \\
\text { Disorder }\end{array}$ \\
\hline 4. How often do you daydream about the Internet? (27) & .789 & & \\
\hline $\begin{array}{l}\text { 1. How often do you fantasize about the Internet, or think about what it would be like to be online when } \\
\text { you are not on the Internet? (15) }\end{array}$ & .752 & & \\
\hline $\begin{array}{l}\text { 7. How often do you feel tense, irritated, or stressed if you cannot use the Internet for as long as you } \\
\text { want to? (25) }\end{array}$ & .693 & & \\
\hline 10. How often do you feel tense, irritated, or stressed if you cannot use the Internet for several days? (28) & 669 & .321 & \\
\hline $\begin{array}{l}\text { 13. How often does it happen to you that you feel depressed, moody, or nervous when you are not on the } \\
\text { Internet and these feelings stop once you are back online? (20) }\end{array}$ & 633 & & \\
\hline 16. How often do you dream about the Internet? (26) & .630 & & \\
\hline 2. How often do you neglect household chores to spend more time online? (2) & & .733 & \\
\hline 5. How often do you spend time online when you'd rather sleep? (14) & & .624 & \\
\hline 8. How often do you choose the Internet rather than being with your partner? (3) & & .572 & \\
\hline 11. How often does the use of the Internet impair your work or your efficacy? (8) & & .531 & .327 \\
\hline 14. How often do people in your life complain about spending too much time online? (5) & & .528 & \\
\hline 17. How often do you choose the Internet rather than going out with somebody to have some fun? (19) & & .457 & \\
\hline 3. How often do you feel that you should decrease the amount of time spent online? (24) & & & .760 \\
\hline $\begin{array}{l}\text { 6. How often does it happen to you that you wish to decrease the amount of time spent online but you do } \\
\text { not succeed? (17) }\end{array}$ & & & .720 \\
\hline 9. How often do you try to conceal the amount of time spent online? (18) & & & .645 \\
\hline 12. How often do you feel that your Internet usage causes problems for you? (22) & & & .602 \\
\hline 15. How often do you realize saying when you are online, "just a couple of more minutes and I will stop"? (16) & & & .488 \\
\hline 18. How often do you think that you should ask for help in relation to your Internet use? (23) & & & .461 \\
\hline
\end{tabular}

Note-The number in parentheses after each item is the original item number (cf. Table 2). Values under .1 are not indicated. Boldface indicates that the item belongs to this particular factor.

the Internet at home. Of the people responding, $61.2 \%$ used the Internet for work for not more than $1 \mathrm{~h}$ daily, whereas the proportion of those who used the Internet for work purposes for more than $5 \mathrm{~h}$ a day was $9 \%$. Besides working, $26.6 \%$ used the Internet for $1 \mathrm{~h}$ daily at the most, and $20.3 \%$ stayed online for more than $5 \mathrm{~h}$. In the sample, the primary aim of Internet use was online communication (chat, IRC) and free surfing on the Internet. The participants spent more than a quarter $(26.4 \%)$ of their online time engaged in the former activity and $22.3 \%$ in the latter activity. The proportions of e-mailing $(16.4 \%)$ and downloading of programs $(11.5 \%)$ were also significant. More than half of the participants $(58.6 \%)$ had 5 relationships, at the most, that were exclusively online connections, whereas the proportion of those having more than 20 exclusively online relationships was $12.2 \%$. Two out of 3 participants had at least 1 relationship that had originally been formed via the Internet but had resulted in a personal meeting, and the proportion of those who had more than five relations like this was $16.8 \%$. Almost two thirds (63\%) of the participants estimated the proportion of their relationships formed on the Internet to be $10 \%$ at the most, whereas $3.6 \%$ originated more than $60 \%$ of their relationships on the Internet.

Regarding problems associated with Internet use, it can be concluded that there are significantly more problems indicated by the PIUQ in the case of those people who primarily use the Internet at home. Consistent with previous research results (Young, 1998b), fewer problems can be identified among those who use the Internet for a longer period. Interestingly, time spent in computer and Internet use had a significant connection with the degree of problems only when computers and the Internet were not used for work purposes. Those whose interpersonal relations were in the main connected with the Internet had significantly more problems on the PIUQ (see Table 9).

\section{Problematic Internet Use and Some Other Deviances}

Of our sample, $65.8 \%$ had been drunk before, $25.1 \%$ had had experiences with illegal drugs, $46.5 \%$ had played on a slot machine before, and $58.2 \%$ had played on a nonwinning gaming machine. Use of illegal drugs and getting drunk did not have a significant relationship with the PIUQ total score, whereas the use of slot machines and non-prize-winning gaming machines was connected with a higher PIUQ mean (see Table 10).

\section{How Problematic Is the "Problematic Internet Use"?}

In the absence of a standard cutoff point-since the results could not be compared either with clinical research results or with other previously validated questionnaires - the obtained score results were grouped according to their deviation from the mean. Four groups were created. The participants with a score that was one standard deviation (9.85) below the mean score belonged to the no-problem (NP) group. Those whose score was one standard deviation, at most, above the mean score belonged to the average-problem (AP) group. The partici- 
Table 4

Means, Standard Deviations, and Corrected Item-Total Correlations of Items With Subscales and the Total Scale

\begin{tabular}{|c|c|c|c|c|}
\hline Item & $M$ & $S D$ & $\begin{array}{l}\text { Corrected } \\
\text { Item-Total } \\
\text { Correlation } \\
\text { (in a Subscale) }\end{array}$ & $\begin{array}{c}\text { Corrected } \\
\text { Item-Total } \\
\text { Correlation } \\
\text { (in the Main Scale) }\end{array}$ \\
\hline \multicolumn{5}{|l|}{ Obsession Scale } \\
\hline 4. How often do you daydream about the Internet? (27) & 1.453 & 0.791 & .681 & .506 \\
\hline $\begin{array}{l}\text { 1. How often do you fantasize about the Internet, or think about what it would be } \\
\text { like to be online, when you are not on the Internet? (15) }\end{array}$ & 1.700 & 0.949 & .688 & .579 \\
\hline $\begin{array}{l}\text { 7. How often do you feel tense, irritated, or stressed if you cannot use the Internet } \\
\text { for as long as you want to? (25) }\end{array}$ & 1.568 & 0.886 & .681 & .611 \\
\hline $\begin{array}{l}\text { 10. How often do you feel tense, irritated, or stressed if you cannot use the Internet } \\
\text { for several days? (28) }\end{array}$ & 1.727 & 0.995 & .664 & .595 \\
\hline $\begin{array}{l}\text { 13. How often does it happen to you that you feel depressed, moody, or nervous when } \\
\text { you are not on the Internet and these feelings stop once you are back online? (20) }\end{array}$ & 1.483 & 0.870 & 607 & .578 \\
\hline 16. How often do you dream about the Internet? (26) & 1.204 & 0.552 & .494 & .384 \\
\hline Obsession (Cronbach's $\alpha=.8477$ ) & 9.135 & 3.855 & & \\
\hline \multicolumn{5}{|l|}{ Neglect Scale } \\
\hline 2. How often do you neglect household chores to spend more time online? (2) & 2.341 & 1.058 & .616 & .565 \\
\hline 5. How often do you spend time online when you'd rather sleep? (14) & 2.756 & 1.223 & .460 & .437 \\
\hline 8. How often do you choose the Internet rather than being with your partner? (3) & 1.598 & 0.952 & .470 & .390 \\
\hline 11. How often does the use of the Internet impair your work or your efficacy? (8) & 1.915 & 0.940 & .422 & .437 \\
\hline $\begin{array}{l}\text { 14. How often do people in your life complain about spending too much time on- } \\
\text { line? (5) }\end{array}$ & 2.254 & 1.243 & .497 & .543 \\
\hline $\begin{array}{l}\text { 17. How often do you choose the Internet rather than going out with somebody to } \\
\text { have some fun? (19) }\end{array}$ & 1.731 & 1.035 & .434 & .455 \\
\hline Neglect (Cronbach's $\alpha=.7425)$ & 12.595 & 4.290 & & \\
\hline \multicolumn{5}{|l|}{ Control Disorder Scale } \\
\hline $\begin{array}{l}\text { 3. How often do you feel that you should decrease the amount of time spent on- } \\
\text { line? (24) }\end{array}$ & 1.951 & 1.029 & .6200 & .480 \\
\hline $\begin{array}{l}\text { 6. How often does it happen to you that you wish to decrease the amount of time } \\
\text { spent online but you do not succeed? (17) }\end{array}$ & 2.034 & 1.154 & .6829 & .577 \\
\hline 9. How often do you try to conceal the amount of time spent online? (18) & 1.536 & 0.945 & .4908 & .435 \\
\hline 12. How often do you feel that your Internet usage causes problems for you? (22) & 1.452 & 0.794 & .4638 & .472 \\
\hline $\begin{array}{l}\text { 15. How often do you realize saying when you are online, "just a couple of more } \\
\text { minutes and I will stop"? (16) }\end{array}$ & 2.629 & 1.211 & .4783 & .523 \\
\hline $\begin{array}{l}\text { 18. How often do you think that you should ask for help in relation to your Internet } \\
\text { use? (23) }\end{array}$ & 1.182 & 0.549 & .3242 & .295 \\
\hline Control disorder (Cronbach's $\alpha=.7614$ ) & 10.784 & 3.944 & & \\
\hline Problematic Internet use (Cronbach's $\alpha=.8725$ ) & 32.513 & 9.847 & & \\
\hline
\end{tabular}

Note-The number in parentheses after each item is the original item number.

pants with a score that was more than one standard deviation above the mean score belonged either to the problem group (PG; with a score less than two standard deviations above the mean) or to the significant-problem (SP) group (with a score more than two standard deviations above the mean) (see Table 11).

People with the fewest problems (NP group) — as compared with the members of the other three groups-are usually older, more typically live in the capital, and more often live with a partner or a spouse (although the rate of those living in their original intact family is also relatively high); they and their fathers more often have a higher education degree, and the working lifestyle is also more frequent among them. They less frequently have Internet access at home and less frequently use a computer or the Internet at home than do members of the other groups. However, the members of this group have been using computers and the Internet for the longest time. They use computers primarily for work, but being online for several hours either for work or for other purposes is not typical of them at all. Regarding their Internet-using habits, members of the NP group most likely surf, e-mail, and study on the Internet and least likely use online communication forms or search for partners. Accordingly to this, as compared with members of the other groups, they have a smaller number of acquaintances originating from the Internet. Surprisingly (although this result is not significant), members of this group were the most likely to use illegal drugs, but the rate of those who had ever played on a slot machine and those who have ever been treated with a mental disorder was lower than in the other groups (see Table 12).

Members of the AP group also typically live in $\mathrm{Bu}-$ dapest, most often in a full family, but the percentage of 
Table 5

Correlations of Subscales With Each Other and With the Main Scale

\begin{tabular}{lccc}
\hline Scale & Obsession & Neglect & Control Disorder \\
\hline Obsession & & .513 & .468 \\
Neglect & & & .501 \\
PIUQ & .802 & .837 & .802 \\
\hline Note_ $p<01$ in every case. & &
\end{tabular}

Table 6

Results of Test-Retest Analysis

\begin{tabular}{lc} 
& Pre-Post Correlation \\
\hline Obsession & .820 \\
Neglect & .904 \\
Control disorder & .763 \\
PIUQ & .903 \\
\hline
\end{tabular}

Note $-p<.0001$ in every case.

Table 7

Gender Differences on the Subscales of PIUQ

\begin{tabular}{llcrrcc}
\hline \multicolumn{1}{c}{ Factor } & Sex & $N$ & $M$ & $S D$ & $F$ & $p$ \\
\hline Obsession & Male & 556 & 9.1 & 3.8 & 0.712 & n.s. \\
& Female & 472 & 9.2 & 3.9 & & \\
Neglect & Male & 556 & 13.0 & 4.4 & 3.441 & .001 \\
Control disorder & Female & 472 & 12.1 & 4.1 & & \\
& Male & 556 & 10.3 & 3.7 & 3.769 & $<.0001$ \\
& Female & 472 & 11.3 & 4.1 & & \\
& Male & 556 & 32.4 & 9.7 & 0.302 & n.s. \\
& Female & 472 & 32.6 & 10.0 & & \\
\hline
\end{tabular}

Table 8

Age Differences on the Subscales of PIUQ

\begin{tabular}{lcccccc}
\hline \multirow{1}{*}{ Factor } & $\begin{array}{c}\text { Age } \\
\text { (years) }\end{array}$ & $N$ & $M$ & $S D$ & $F$ & $p$ \\
\hline Obsession & $12-18$ & 341 & 1.71 & 0.76 & 22.902 & $<.0001$ \\
& $19-28$ & 480 & 1.43 & 0.55 & & \\
Neglect & $29-69$ & 205 & 1.43 & 0.57 & & \\
& $12-18$ & 341 & 2.18 & 0.67 & 4.364 & $<.0001$ \\
Control disorder & $19-28$ & 480 & 2.03 & 0.72 & & \\
& $29-69$ & 205 & 2.12 & 0.76 & & \\
PIUQ & $12-18$ & 341 & 1.92 & 0.68 & 9.744 & .013 \\
& $19-28$ & 480 & 1.72 & 0.61 & & \\
& $29-69$ & 205 & 1.78 & 0.70 & & \\
& $12-18$ & 341 & 34.89 & 9.83 & 15.681 & $<.0001$ \\
& $19-28$ & 480 & 31.08 & 9.44 & & \\
\hline
\end{tabular}

singles is the highest among them. Approximately half of them work, and half of them are students. Like the groups with more problems, they most often use the Internet at home. The members of this group use computers for work and for other purposes equally intensively. However, a greater amount of Internet use (similarly to people with scores above average) is connected to Internet use for nonworking purposes. People with average scores use the Internet for surfing, online communication, and e-mailing in a similar proportion, and this is the group that browses porn pages in the highest proportion. Using the Internet to find a partner is more likely in this group than in the previous group, and accordingly, other forms of acquaintance making are also frequent.
Members of the group with a score one standard deviation above the mean score (PG) are the youngest, and the proportion of women $(51.5 \%)$ is the highest among them. The percentage of those living in Budapest is the lowest in this group, and they most likely live in a family and primarily study. The proportion of those having only an elementary school qualification is the highest, and the percentage of those having a higher education degree is the lowest in this group - partly due to their age. They most often use computers and the Internet for nonwork purposes. Online communication (chat) and making acquaintances online characterize their Internet use. Many of them have acquaintances maintained exclusively via the Internet, but relations originating from the Internet and resulting in a personal meeting are highly typical in this group.

The group with the most problems (SP) had the highest proportion of men. Members of this group, as compared with the other groups, live most likely in a restructured family and least likely in an intact family. The proportion of those living with a partner or a spouse is the lowest in this group. Nevertheless, none of the family structures is prominent in this group. The percentage who have fathers with a higher education degree is the lowest for this group, and as in the previous group, there is a high proportion of those having only an elementary school qualification and a low proportion of those having a higher education degree (although the average age in this group is 2 years higher than in the PG group). Although their primary occupation is studying, as in the previous two groups, the proportion of those having no occupation (not working and not studying), as compared with the other groups, is more than twice as high (6.7\%). Members of this group are the "newest" users of computers and the Internet; that is, they have been using these devices for the shortest time (for 6.8 and 2.4 years, on average). The proportion of those using a computer and the Internet for hours and hours for nonwork purposes is the highest in this group. Whereas exactly one third (33\%) of the PG members use the Internet for nonwork reasons for more than $35 \mathrm{~h}$ weekly, among members of the SP group, this proportion is $46.3 \%$ (for the AP group, this proportion is $19.1 \%$, whereas for the NP group, it is 5.8\%). Of the different purposes of Internet use, online communication is the most characteristic of this group, and the proportion of those using the Internet to find a partner is also the highest in this group. Number of acquaintances originating from the Internet is also high, but the proportion of relations originating from the Internet and resulting in a personal meeting is similar to that for the AP group. Thus, in the SP group, there is a lower likelihood of meeting in person people whom they met originally via the Internet. With regard to deviant behaviors, the proportion of those who have ever played on a slot machine is the highest in this group.

\section{DISCUSSION}

Regarding its psychometric features and its contents, the PIUQ (see the Appendix) proved to be a useful assessment tool for measuring problems in connection with Internet use. Since the full scale and the subscales have 
Table 9

Relation Between Some Characteristics of Internet Use and the PIUQ

\begin{tabular}{|c|c|c|c|c|c|c|}
\hline \multirow[b]{2}{*}{ Item } & \multirow[b]{2}{*}{ Response } & \multirow[b]{2}{*}{$n$} & \multicolumn{2}{|c|}{ PIUQ } & \multirow[b]{2}{*}{$t / F$} & \multirow[b]{2}{*}{$p$} \\
\hline & & & $M$ & $S D$ & & \\
\hline Where do you use the Internet primarily? & $\begin{array}{l}\text { At home } \\
\text { At workplace }\end{array}$ & $\begin{array}{l}536 \\
226\end{array}$ & $\begin{array}{l}34.6 \\
29.0\end{array}$ & $\begin{array}{r}10.1 \\
8.9\end{array}$ & 7.56 & $<.0001$ \\
\hline For how many years have you been using the Internet? & $\begin{array}{l}0-1 \text { year } \\
1-2 \text { years } \\
2-4 \text { years } \\
\text { More than } 4 \text { years }\end{array}$ & $\begin{array}{l}257 \\
231 \\
320 \\
212\end{array}$ & $\begin{array}{l}34.1 \\
32.6 \\
32.9 \\
29.9\end{array}$ & $\begin{array}{r}9.6 \\
9.9 \\
10.4 \\
8.6\end{array}$ & 7.742 & $<.0001$ \\
\hline $\begin{array}{l}\text { How many hours in a week, on average, do you spend with a computer not } \\
\text { being used for work purposes? }\end{array}$ & $\begin{array}{l}0-7 \mathrm{~h} \\
8-35 \mathrm{~h} \\
36 \mathrm{~h} \text { or more }\end{array}$ & $\begin{array}{l}162 \\
412 \\
224\end{array}$ & $\begin{array}{l}27.6 \\
32.5 \\
38.5\end{array}$ & $\begin{array}{r}7.5 \\
9.3 \\
10.9\end{array}$ & 65.247 & $<.0001$ \\
\hline $\begin{array}{l}\text { How many hours in a week, on average, do you spend on the Internet other } \\
\text { than for work purposes? }\end{array}$ & $\begin{array}{l}0-7 \mathrm{~h} \\
8-35 \mathrm{~h} \\
36 \mathrm{~h} \text { or more }\end{array}$ & $\begin{array}{l}217 \\
434 \\
166\end{array}$ & $\begin{array}{l}28.5 \\
33.3 \\
38.5\end{array}$ & $\begin{array}{r}8.8 \\
9.5 \\
10.8\end{array}$ & 50.389 & $<.0001$ \\
\hline $\begin{array}{l}\text { How many relationships do you have that are maintained exclusively via the } \\
\text { Internet? }\end{array}$ & $\begin{array}{l}0 \\
1-5 \\
\text { More than } 5\end{array}$ & $\begin{array}{l}132 \\
352 \\
343\end{array}$ & $\begin{array}{l}28.9 \\
31.7 \\
36.2\end{array}$ & $\begin{array}{r}8.9 \\
9.3 \\
10.6\end{array}$ & 32.391 & $<.0001$ \\
\hline $\begin{array}{l}\text { How many relations do you have that were originally created on the Internet } \\
\text { but later resulted in a personal meeting? }\end{array}$ & $\begin{array}{l}0 \\
1-5 \\
\text { More than } 5\end{array}$ & $\begin{array}{l}267 \\
334 \\
225\end{array}$ & $\begin{array}{l}31.3 \\
33.1 \\
35.4\end{array}$ & $\begin{array}{r}9.8 \\
9.9 \\
10.6\end{array}$ & 9.927 & $<.0001$ \\
\hline What proportion of your circle of acquaintances had an online origin? & $\begin{array}{l}0 \%-10 \% \\
10 \%-100 \%\end{array}$ & $\begin{array}{l}521 \\
306\end{array}$ & $\begin{array}{l}31.4 \\
36.2\end{array}$ & $\begin{array}{r}9.5 \\
10.6\end{array}$ & 6.533 & $<.0001$ \\
\hline What proportion of your close friendships had an online origin? & $\begin{array}{l}0 \%-10 \% \\
10 \%-100 \%\end{array}$ & $\begin{array}{l}598 \\
230\end{array}$ & $\begin{array}{l}31.6 \\
36.9\end{array}$ & $\begin{array}{r}9.6 \\
10.7\end{array}$ & 6.597 & $<.0001$ \\
\hline
\end{tabular}

a high inner consistency and the PIUQ has a favorable test-retest reliability and a coherence in its conception and contents, the further use of this questionnaire seems to be reasonable. The results about the habits of Internet use partly support the validity of the questionnaire, but in this area, further research is needed. Tests of the questionnaire with representative samples of the normal population, with offline data collection, have just begun. Regarding its contents and structure, the PIUQ fits the results of previous research and also complements them. The resulting three-factor model reflects the results of the analysis of the original IAT questionnaire (Widyanto \& McMurran, 2004) and indicates that the modification of the questionnaire was indeed needed. In the PIUQ, 11 (modified or unaltered) items of the original IAT scale were kept, and an additional 7 new items were added to the questionnaire of Young (1998a). As a result, PIUQ has a more compact, more tense factor structure and does not include less substantial factors with 2 or 3 items (IAT has four factors like that out of six) that would be difficult to interpret as a scale. Of the four factors reflecting cognitive processes more than behaviors that were described by Davis et al. (2002), impulse control disorder and, partly, the factor of distraction were reproduced in the PIUQ model. Presumably, dissenting conceptions are responsible for the differences. Although different studies have resulted in slightly different factor structures (see, e.g., Caplan, 2002; Pratarelli \& Browne, 2002), observations support the multifactor model of Internet addiction, and not the one-factor model of Nichols and Nicki (2004).

The results for the characteristics of Internet use correspond to previous observations. As in other research (see, e.g., Kandell, 1998), the adolescent and young adult population was found to be the most endangered. Work proved

Table 10

Relation Between Some Deviances and the PIUQ

\begin{tabular}{|c|c|c|c|c|c|c|}
\hline \multirow[b]{2}{*}{ Deviance } & \multirow[b]{2}{*}{ Response } & \multirow[b]{2}{*}{$n$} & \multicolumn{2}{|c|}{ PIUQ } & \multirow[b]{2}{*}{$t / F$} & \multirow[b]{2}{*}{$p$} \\
\hline & & & $M$ & $S D$ & & \\
\hline Ever used illegal drugs & $\begin{array}{l}\text { Never } \\
1-10 \text { times } \\
\text { More than } 10 \text { times }\end{array}$ & $\begin{array}{r}591 \\
123 \\
75\end{array}$ & $\begin{array}{l}32.9 \\
33.3 \\
33.4\end{array}$ & $\begin{array}{l}10.1 \\
10.3 \\
11.1\end{array}$ & 0.131 & n.s. \\
\hline Ever played on a slot machine & $\begin{array}{l}\text { Never } \\
1-10 \text { times } \\
\text { More than } 10 \text { times }\end{array}$ & $\begin{array}{l}425 \\
264 \\
105\end{array}$ & $\begin{array}{l}32.2 \\
33.3 \\
35.5\end{array}$ & $\begin{array}{l}10.0 \\
10.3 \\
10.6\end{array}$ & 4.501 & .011 \\
\hline Ever played on a nonwinning gaming machine & $\begin{array}{l}\text { Never } \\
1-10 \text { times } \\
\text { More than } 10 \text { times }\end{array}$ & $\begin{array}{l}341 \\
247 \\
202\end{array}$ & $\begin{array}{l}32.9 \\
32.1 \\
34.7\end{array}$ & $\begin{array}{r}10.5 \\
9.5 \\
10.5\end{array}$ & 3.691 & .025 \\
\hline Ever been drunk & $\begin{array}{l}\text { Never } \\
1-10 \text { times } \\
\text { More than } 10 \text { times }\end{array}$ & $\begin{array}{l}278 \\
241 \\
294\end{array}$ & $\begin{array}{l}32.1 \\
33.4 \\
33.7\end{array}$ & $\begin{array}{r}9.7 \\
9.8 \\
10.9\end{array}$ & 1.924 & n.s. \\
\hline
\end{tabular}


Table 11

Groups Created According to the PIUQ

\begin{tabular}{|c|c|c|c|c|c|}
\hline Groups & $n$ & $\%$ & $\begin{array}{c}\text { Score } \\
\text { (According to Definition) }\end{array}$ & $M$ & $S D$ \\
\hline No problems & 136 & 13.1 & $<22.7$ & 20.4 & 1.3 \\
\hline Few/average problems & 751 & 72.4 & $22.7 \leq$ score $\leq 42.4$ & 31.1 & 5.5 \\
\hline Problems present & 105 & 10.1 & $42.4<$ score $\leq 52.2$ & 46.7 & 2.8 \\
\hline Significant problems & 45 & 4.3 & $>52.2$ & 59.4 & 5.3 \\
\hline
\end{tabular}

to be a protective factor, whereas having no occupation that could structure time and everyday activities was a definite risk factor. This observation is also supported by the result, which had not previously been produced, that problematic Internet use does not have a close connection with time spent generally with Internet use but does have a connection with time spent online for nonwork purposes. The previous observation - that people who have used the Internet for a shorter time are more problematic than people who have been using the Internet for a lon- ger time (Nyikos et al., 2001; Young, 1998b) —was also reproduced. Similarly to the findings in the longitudinal study of Kraut et al. (2002), it can be assumed that initially more intensive, compulsive use will normalize with time. Results of the presented study - according to previous observations (see, e.g., Davis et al., 2002; Kubey, Lavin, \& Barrows, 2001; Leung, 2004) - indicate clearly that in the case of users with more problems the use of online simultaneous communication forms dominates, whereas surfing, e-mailing, and using the Internet for study purposes

Table 12

Description of the Four Groups Based on Some Fundamental Aspects

\begin{tabular}{|c|c|c|c|c|c|c|}
\hline \multirow[b]{2}{*}{ Characteristic } & \multicolumn{4}{|c|}{ Group } & \multirow{2}{*}{$\begin{array}{l}\text { Statistics } \\
\left(t / F / \chi^{2}\right)\end{array}$} & \multirow[b]{2}{*}{$p^{\mathrm{a}}$} \\
\hline & NP & AP & PG & SP & & \\
\hline Male (\%) & 53.7 & 54.8 & 48.5 & 55.6 & 0.686 & n.s. \\
\hline Mean age (years) & 25.2 & 23.2 & 21.7 & 23.6 & 3.075 & $.027^{\mathrm{b}}$ \\
\hline Proportion of inhabitants of Budapest (\%) & 49.2 & 45.3 & 30.1 & 37.8 & & \\
\hline Intact family (\%) & 34.4 & 46.3 & 47.0 & 43.6 & & \\
\hline Singles $(\%)$ & 2.9 & 9.9 & 7.6 & 6.7 & & \\
\hline Living with a partner or spouse $(\%)$ & 38.2 & 20.9 & 19.0 & 17.8 & & \\
\hline Primarily learning $(\%)$ & 36.6 & 52.4 & 59.8 & 57.8 & & \\
\hline Primarily working (\%) & 58.8 & 42.7 & 37.1 & 33.3 & & \\
\hline Not having an occupation at all (\%) & 3.1 & 3.1 & 3.1 & 6.7 & & \\
\hline Elementary school education at the most (\%) & 14.2 & 28.1 & 38.6 & 35.6 & & \\
\hline Higher education degree $(\%)$ & 34.3 & 23.3 & 17.8 & 17.8 & & \\
\hline Having access to the Internet at home (\%) & 64.4 & 82.3 & 90.5 & 84.4 & & \\
\hline Using a computer primarily at home $(\%)$ & 45.6 & 68.2 & 82.4 & 84.2 & & \\
\hline Using the Internet primarily at home (\%) & 44.7 & 71.9 & 85.7 & 85.7 & & \\
\hline Number of years they have used the Internet & 3.7 & 2.9 & 2.7 & 2.4 & 9.104 & $<.0001$ \\
\hline Uses the computer for work for more than $35 \mathrm{~h}$ a week $(\%)$ & 34.4 & 24.9 & 25.5 & 28.6 & & \\
\hline Uses the computer for things other than work for more than $35 \mathrm{~h}$ a week $(\%)$ & 8.9 & 25.4 & 51.6 & 60.0 & & \\
\hline Uses the Internet for work for more than $35 \mathrm{~h}$ a week $(\%)$ & 9.4 & 8.3 & 14.0 & 10.0 & & \\
\hline Uses the Internet not for work for more than $35 \mathrm{~h}$ a week $(\%)$ & 5.8 & 19.1 & 33.0 & 46.3 & & \\
\hline Using the Internet for surfing & 30.5 & 22.1 & 16.2 & 15.1 & 12.136 & $<.0001$ \\
\hline Using the Internet for online communication (chat, IRC) & 12.2 & 27.1 & 36.1 & 37.3 & 21.674 & $<.0001$ \\
\hline Using the Internet for e-mailing & 24.3 & 15.9 & 12.5 & 10.1 & 14.195 & $<.0001$ \\
\hline Using the Internet for looking at sex pages & 1.3 & 3.8 & 2.8 & 2.5 & 3.651 & .012 \\
\hline Using the Internet for studying & 7.0 & 5.0 & 3.7 & 3.1 & 4.120 & .007 \\
\hline Using the Internet for finding a partner & 1.7 & 3.9 & 3.6 & 6.9 & 3.209 & .023 \\
\hline More than 5 relationships maintained exclusively online $(\%)$ & 22.6 & 40.5 & 60.4 & 61.9 & 36.436 & $<.0001$ \\
\hline More than 5 relationships established online and later resulting in a personal meeting (\%) & 18.9 & 26.6 & 40.2 & 28.6 & 11.717 & .008 \\
\hline More than $10 \%$ of acquaintances originated from the Internet $(\%)$ & 21.0 & 36.1 & 53.3 & 54.8 & 27.946 & $<.0001$ \\
\hline More than $10 \%$ of friends originated from the Internet $(\%)$ & 12.3 & 26.3 & 48.9 & 41.5 & 37.657 & $<.0001$ \\
\hline $\begin{array}{l}\text { More than } 10 \% \text { of acquaintances originated from the Internet but resulted in a personal } \\
\text { meeting }(\%)\end{array}$ & 12.3 & 20.9 & 40.2 & 31.0 & 25.523 & $<.0001$ \\
\hline Played on a slot machine $(\%)$ & 37.5 & 47.2 & 47.0 & 58.5 & 5.885 & n.s. \\
\hline Ever played on a game machine (not for winning) (\%) & 53.4 & 57.7 & 58.1 & 51.2 & 1.245 & n.s. \\
\hline Ever got drunk (\%) & 67.6 & 64.7 & 67.0 & 73.8 & 1.720 & n.s. \\
\hline Ever been treated for psychiatric disorder $(\%)$ & 2.8 & 6.9 & 6.6 & 7.1 & 2.611 & n.s. \\
\hline
\end{tabular}


is characteristic of users with fewer problems. This result is not surprising, when one considers that chat (simultaneous online communication) reflects the fundamental characteristic of addictions: deficiency of self-regulation, and an insufficient ability to delay gratification (Demetrovics, 2007) - contrary to, for example, e-mails, whose use requires the ability to wait longer for the answer (Grezsa, Takács, \& Demetrovics, 2001).

Finally, the threefold question of terminology, definition, and assessment, mentioned in the introduction, should be reconsidered. With regard to the question of naming the phenomenon, the terming of this questionnaire expresses the idea that that the term Internet addiction should be reserved for the description of excessive Internet use with clinical significance and must be separated from problematic use in general. The former requires clinical attention, whereas the latter-although several problems in everyday life are indicated - can be considered a symptomatic behavior. Research of the authors and previous studies (see, e.g., Griffiths, 2000) indicate that the majority of people who use the Internet in an excessive degree do not have problems that are so serious as to require clinical attention and be called an Internet addiction. Moreover, the observed phenomenon is often temporary. The gravity of the problems may decrease with time. However, the question deserves to be investigated also from a methodological point of view. From this point of view, a problem might arise because studies with questionnaires have not yet been supplemented by clinical interviewing methods; thus, real clinical validity tests do not exist for any of the measuring devices. When assessing the problem with questionnaires, most authors have not determined cutoff points, and in those few devices in which they have, it was done in an ad hoc, arbitrary way. The latter tendency also indicates the above-mentioned methodological problem. However, considering that there has been an increasing number of suggestions for the diagnosis, with increasing concreteness (Beard, 2005; Beard \& Wolf, 2001; Shapira et al., 2003), and that psychiatric interview methods for diagnosing the problem have been created (Shapira et al., 2000 ), there are fewer and fewer difficulties in making validity tests of the questionnaire methods.

In some summaries, an attempt often has been made to emphasize the relation between Internet addiction and psychoactive substance dependence, pathological gambling, and, perhaps, other impulse control disorders. Supposedly, this distinction is not as significant as it seems at first glance. Although the $D S M-I V$ classifies these disorders in different classes, their close relationship is obvious. The central symptom of psychoactive substance use is the inability to control impulses, and the addictive nature of impulse control disorders cannot be debated. Defining them collectively as behavioral addictions (see, e.g., Marks, 1990) resolves this apparent contradiction, just as the conception of Hollander about obsessive-compulsive spectrum disorders (Hollander, 1993; Hollander \& Wong, 1995) created a theoretical frame in which the common etiological and symptomatic characteristics of the different disorders became perceivable. These behaviors are not only similar in their symptoms, which are difficulties in controlling impulses, an increased search for novelties (in relation to Internet addiction, see, e.g., Ko et al., 2006), dangerousness for self and environment, and their ritualized, repetitive (compulsive, addictive) nature. Psychogenetic and neurobiological research of the past years also has indicated that similar symptomatic patterns are connected to similar neurobiological dysfunctions According to the studies of Blum and coworkers, this dysfunction could primarily be a disorder in dopamine transmission that has a major role in the functioning of the mesencephalic reward system (Blum et al., 2000; Blum et al., 1995). Today, it is unknown to what extent this phenomenoncalled reward deficiency syndrome (Comings \& Blum, 2000) - characterizes excessive Internet users, since related research has not been conducted yet. However, regarding the results above and those of previous research, it seems that interpretation of the phenomenon of problematic Internet use in a behavioral addiction frame could be a reasonable approach. There are major symptomssuch as control disorder (PIUQ, third factor), which is an unconquerable desire to engage in a given conduct, and, in connection with this, engagement in thoughts (first factor), the appearance of withdrawal symptoms (especially in cases in which implementing an action is prevented), and probably the most significant sign of problems, neglect of life areas that were previously considered to be important - that are shared characteristics of all chemical and behavioral addictions, including Internet addiction. Finding the place of Internet addiction in the model proposed by Hollander and Wong (1995) will be an objective of future research. It seems to be clear that problematic Internet use has both compulsive and impulsive symptoms; however, the proportion of these symptoms has not yet been revealed.

\section{AUTHOR NOTE}

This research was supported by Grant KAB-KT-02-13 from the Ministry of Children, Youth, and Sport in Hungary. Correspondence concerning this article should be addressed to Z. Demetrovics, Addiction Research Unit, Eötvös Loránd University, P.O. Box 179, Budapest H-1580, Hungary (e-mail: demetrovics@t-online.hu).

\section{REFERENCES}

American Psychiatric Association (1994). Diagnostic and statistical manual of mental disorders (4th ed.) (DSM-IV). Washington, DC: Author

Armstrong, L., Phillips, J. G., \& Saling, L. L. (2000). Potential determinants of heavier Internet usage. International Journal of HumanComputer Studies, 53, 537-550.

BAI, Y.-M., LIN, C.-C., \& CHEN, J.-Y. (2001). Internet addiction disorder among clients of a virtual clinic. Psychiatric Services, 52, 1397.

BEARD, K. W. (2005). Internet addiction: A review of current assessment techniques and potential assessment questions. CyberPsychology \& Behavior, 8, 7-14.

BEARD, K. W., \& Wolf, E. M. (2001). Modification in the proposed diagnostic criteria for Internet addiction. CyberPsychology \& Behavior, 4, 377-383.

Belsare, T. J., Gaffney, G. R., \& Black, D. W. (1997). Compulsive computer use. American Journal of Psychiatry, 154, 289.

Blum, K., Braverman, E. R., Holder, J. M., Lubar, J. F., Monastra, V. J., Miller, D., ET AL. (2000). Reward deficiency syndrome: A biogenetic model for the diagnosis and treatment of impulsive, addictive, and compulsive behaviors. Journal of Psychoactive Drugs, 32(Suppl. i-iv), 1-112. 
Blum, K., Sheridan, P. J., Wood, R. C., Braverman, E. R., Chen, T. J., \& Comings, D. E. (1995). Dopamine D2 receptor gene variants: Association and linkage studies in impulsive-addictive-compulsive behaviour. Pharmacogenetics, 5, 121-141.

Brenner, V. (1997). Psychology of computer use: XLVII. Parameters of Internet use, abuse and addiction: The first 90 days of the Internet Usage Survey. Psychological Reports, 80, 879-882.

Caplan, S. E. (2002). Problematic Internet use and psychosocial wellbeing: Development of a theory-based cognitive-behavioral measurement instrument. Computers in Human Behavior, 18, 553-575.

ChaK, K., \& Leung, L. (2004). Shyness and locus of control as predictors of Internet addiction and Internet use. CyberPsychology \& Behavior, 7, 559-570.

Chou, C., Condron, L., \& Belland, J. C. (2005). A review of the research on Internet addiction. Educational Psychology Review, 17, 363-388.

Comings, D. E., \& Blum, K. (2000). Reward deficiency syndrome: Genetic aspects of behavioral disorders. Progress in Brain Research, 126, 325-341.

Cronk, B. C., \& West, J. L. (2002). Personality research on the Internet: A comparison of Web-based and traditional instruments in take-home and in-class settings. Behavior Research Methods, Instruments, \& Computers, 34, 177-180.

DAVIS, R. A. (2001). A cognitive-behavioral model of pathological Internet use. Computers in Human Behavior, 17, 187-195.

Davis, R. A., Flett, G. L., \& Besser, A. (2002). Validation of a new scale for measuring problematic Internet use: Implications for preemployment screening. CyberPsychology \& Behavior, 5, 331-345.

Demetrovics, Z. (2007). A droghasználat funkciói [The functions of drug use]. Budapest: Academic Press.

GOLDBERG, I. (1995). Internet addictive disorder (IAD) diagnostic criteria. Retrieved July 27, 2007, from www.psycom.net/iadcriteria.html.

GreENFIELD, D. N. (1999). Psychological characteristics of compulsive Internet use: A preliminary analysis. CyberPsychology \& Behavior, 2, 403-412.

Grezsa, F. S., TAKÁcs, Z., \& Demetrovics, Z. (2001). www.necc.huIfjúsági Mentálhigiénés Szolgálat az Interneten [www.necc.hu-An online youth mental health service]. Új Pedagógiai Szemle, 5, 115-120.

Griffiths, M. (1997). Psychology of computer use: XLIII. Some comments on "Addictive use of the Internet" by Young. Psychological Reports, 80, 81-82.

GRIFFITHS, M. (2000). Does Internet and computer "addiction" exist? Some case study evidence. CyberPsychology \& Behavior, 3, 211-218.

HANSEN, S. (2002). Excessive Internet usage or "Internet addiction"? The implications of diagnostic categories for student users. Journal of Computer Assisted Learning, 18, 232-236.

Hollander, E. (1993). Obsessive-compulsive spectrum disorders: An overview. Psychiatric Annals, 23, 355-358.

Hollander, E., \& Wong, C. M. (1995). Obsessive-compulsive spectrum disorders. Journal of Clinical Psychiatry, 56(Suppl. 4), 3-6; discussion 53-55.

KANDELL, J. J. (1998). Internet addiction on campus: The vulnerability of college students. CyberPsychology \& Behavior, 1, 11-17.

Ko, C.-H., Yen, J.-Y., Chen, C.-C., Chen, S.-H., Wu, K., \& Yen, C.-F. (2006). Tridimensional personality of adolescents with Internet addiction and substance use experience. Canadian Journal of Psychiatry, 51, 887-894

Koch, W. H., \& Pratarelli, M. E. (2004). Effects of intro/extraversion and sex on social Internet use. North American Journal of Psychology, 6, 371-382.

Kraut, R., Kiesler, S., Boneva, B., Cummings, J., Helgeson, V., \& Crawford, A. (2002). Internet paradox revisited. Journal of Social Issues, 58, 49-74

Kraut, R., Patterson, M., Lundmark, V., Kiesler, S., MukoPADHYAY, T., \& SCHERLIS, W. (1998). Internet paradox: A social tech- nology that reduces social involvement and psychological well-being? American Psychologist, 53, 1017-1031.

Kubey, R. W., LAVIN, M. J., \& Barrows, J. R. (2001). Internet use and collegiate academic performance decrements: Early findings. Journal of Communication, 51, 366-382.

LEUNG, L. (2004). Net-generation attributes and seductive properties of the Internet as predictors of online activities and Internet addiction. CyberPsychology \& Behavior, 7, 333-348.

MARKS, I. (1990). Behavioural (non-chemical) addictions. British Journal of Addiction, 85, 1389-1394.

Mitchell, P. (2000). Internet addiction: Genuine diagnosis or not? Lancet, 355, 632.

Morahan-Martin, J. (2005). Internet abuse: Addiction? Disorder? Symptom? Alternative explanations? Social Science Computer Review, 23, 39-48.

Morahan-Martin, J., \& Schumacher, P. (2000). Incidence and correlates of pathological Internet use among college students. Computers in Human Behavior, 16, 13-29.

NaLwa, K., \& ANAND, A. P. (2003). Internet addiction in students: A cause of concern. CyberPsychology \& Behavior, 6, 653-656.

NichOLs, L. A., \& NiCKI, R. (2004). Development of a psychometrically sound Internet addiction scale: A preliminary step. Psychology of Addictive Behaviors, 18, 381-384.

Nyikos, E., Szeredi, B., \& Demetrovics, Z. (2001). Egy új viselkedéses addikció: Az Internethasználat személyiségpszichológiai korrelátumai [A new behavioral addiction: The personality psychological correlates of Internet use]. Pszichoterápia, 10, 168-182.

Pratarelli, M. E., \& Browne, B. L. (2002). Confirmatory factor analysis of Internet use and addiction. CyberPsychology \& Behavior, 5, 53-64.

Pratarelli, M. E., Browne, B. L., \& Johnson, K. (1999). The bits and bytes of computer/Internet addiction: A factor analytic approach. $B e$ havior Research Methods, Instruments, \& Computers, 31, 305-314.

Shapira, N. A., Goldsmith, T. D., Keck, P. E., Jr., Khosla, U. M., \& McElroy, S. L. (2000). Psychiatric features of individuals with problematic Internet use. Journal of Affective Disorders, 57 267-272.

Shapira, N. A., Lessig, M. C., Goldsmith, T. D., Szabo, S. T., Lazoritz, M., Gold, M. S., \& Stein, D. J. (2003). Problematic Internet use: Proposed classification and diagnostic criteria. Depression \& Anxiety, 17, 207-216

Treuer, T., FÁBIÁN, Z., \& FÜredi, J. (2001). Internet addiction associated with features of impulse control disorder: Is it a real psychiatric disorder? Journal of Affective Disorders, 66, 283.

WhANG, L. S., LeE, S., \& CHANG, G. (2003). Internet over-users' psychological profiles: A behavior sampling analysis on Internet addiction. CyberPsychology \& Behavior, 6, 143-150.

Widyanto, L., \& McMurran, M. (2004). The psychometric properties of the Internet addiction test. CyberPsychology \& Behavior, 7, 443-450.

Young, K. S. (1996). Psychology of computer use: XL. Addictive use of the Internet: A case that breaks the stereotype. Psychological Reports, 79, 899-902.

Young, K. S. (1998a). Caught in the Net: How to recognize the signs of Internet addiction - and a winning strategy for recovery. New York: Wiley.

YounG, K. S. (1998b). Internet addiction: The emergence of a new clinical disorder. CyberPsychology \& Behavior, 1, 237-244

Young, K. S., \& Rodgers, R. C. (1998). The relationship between depression and Internet addiction. CyberPsychology \& Behavior, 1 25-28.

Yuen, C. N., \& LAVIN, M. J. (2004). Internet dependence in the collegiate population: The role of shyness. CyberPsychology \& Behavior, 7, 379-383. 


\section{APPENDIX}

Problematic Internet Use Questionnaire (PIUQ)

In the following you will read statements about your Internet use. Please indicate on a scale from 1 to 5 how much these statements characterize you.

\begin{tabular}{|c|c|c|c|c|c|}
\hline & $\bar{d}_{\bar{d}}^{\bar{d}}$ & 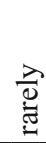 & 岂 & 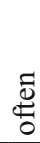 & $\frac{\sqrt{2}}{\frac{3}{\pi}}$ \\
\hline \multicolumn{6}{|l|}{ 1. How often do you fantasize about the Internet, or think about what it would be } \\
\hline like to be online when you are not on the Internet? & 1 & 2 & 3 & 4 & 5 \\
\hline 2. How often do you neglect household chores to spend more time online? & 1 & 2 & 3 & 4 & \\
\hline $\begin{array}{l}\text { 3. How often do you feel that you should decrease the amount of time spent } \\
\text { online? }\end{array}$ & 1 & 2 & 3 & 4 & 5 \\
\hline 4. How often do you daydream about the Internet? & 1 & 2 & 3 & 4 & 5 \\
\hline 5. How often do you spend time online when you'd rather sleep? & 1 & 2 & 3 & 4 & 5 \\
\hline $\begin{array}{l}\text { 6. How often does it happen to you that you wish to decrease the amount of time } \\
\text { spent online but you do not succeed? }\end{array}$ & 1 & 2 & 3 & 4 & 5 \\
\hline $\begin{array}{l}\text { 7. How often do you feel tense, irritated, or stressed if you cannot use the Inter- } \\
\text { net for as long as you want to? }\end{array}$ & 1 & 2 & 3 & 4 & 5 \\
\hline 8. How often do you choose the Internet rather than being with your partner? & 1 & 2 & 3 & 4 & 5 \\
\hline 9. How often do you try to conceal the amount of time spent online? & 1 & 2 & 3 & 4 & 5 \\
\hline $\begin{array}{l}\text { 10. How often do you feel tense, irritated, or stressed if you cannot use the Inter- } \\
\text { net for several days? }\end{array}$ & 1 & 2 & 3 & 4 & 5 \\
\hline 11. How often does the use of Internet impair your work or your efficacy? & 1 & 2 & 3 & 4 & 5 \\
\hline 12. How often do you feel that your Internet usage causes problems for you? & 1 & 2 & 3 & 4 & 5 \\
\hline $\begin{array}{l}\text { 13. How often does it happen to you that you feel depressed, moody, or nervous } \\
\text { when you are not on the Internet and these feelings stop once you are back } \\
\text { online? }\end{array}$ & 1 & 2 & 3 & 4 & 5 \\
\hline $\begin{array}{l}\text { 14. How often do people in your life complain about spending too much time } \\
\text { online? }\end{array}$ & 1 & 2 & 3 & 4 & 5 \\
\hline $\begin{array}{l}\text { 15. How often do you realize saying when you are online, "just a couple of more } \\
\text { minutes and I will stop"? }\end{array}$ & 1 & 2 & 3 & 4 & 5 \\
\hline 16. How often do you dream about the Internet? & 1 & 2 & 3 & 4 & 5 \\
\hline $\begin{array}{l}\text { 17. How often do you choose the Internet rather than going out with somebody to } \\
\text { have some fun? }\end{array}$ & 1 & 2 & 3 & 4 & 5 \\
\hline $\begin{array}{l}\text { 18. How often do you think that you should ask for help in relation to your Internet } \\
\text { use? }\end{array}$ & 1 & 2 & 3 & 4 & 5 \\
\hline
\end{tabular}

Subscales

Obsession: Questions 1, 4, 7, 10, 13, 16

Neglect: Questions 2, 5, 8, 11, 14, 17

Control disorder: Questions 3, 6, 9, 12, 15, 18

(Manuscript received October 27, 2007; accepted for publication December 7, 2007.) 